\title{
A PRACTICAL APPLICATION FOR MONITORING METHANE IN AMBIENT AIR AT WASTE DISPOSAL FACILLITIES USING A PORTABLE OPEN PATH ANALYZER
}

\author{
Noboru Tanikawa \\ Toru Furuichi \\ Kazuei Ishii \\ Kohji Matsuo \\ Hokkaido University, Japan
}

\begin{abstract}
It is well known that methane $\left(\mathrm{CH}_{4}\right)$ is a greenhouse gas, and one of the main gases emitted from landfills. $\mathrm{CH}_{4}$ is also emitted from biogasification facilities and composting facilities. A new method to monitor $\mathrm{CH}_{4}$ in ambient air has been developed using a portable open path methane analyzer (POMA) that is retailed as an urban gas leak detector. In this study, we have investigated a practical application of a POMA in the field, and the characteristics of $\mathrm{CH}_{4}$ emissions at landfill sites, biogasification facilities, and a composting facility.

It is clear that this new method is convenient, and can be used to monitor the average concentration of $\mathrm{CH}_{4}$ in ambient air at a waste disposal facility, such as a landfill site, a composting facility, or a biogasification facility. The concentration of $\mathrm{CH}_{4}$ in ambient air at landfill sites, a composting facility, and biogasification facilities were found to be $2-30,2-13$, and 3-13 ppm, respectively.
\end{abstract}

\section{KEYWORDS}

Methane; Open path type analyzer; Landfill site; Biogasification; Composting

\section{INTRODUCTION}

Methane $\left(\mathrm{CH}_{4}\right)$ is known to be a major greenhouse gas emitted from landfill sites. It is necessary to measure the volume of methane emitted from landfill sites to judge the stability of a landfill site, and to examine its contribution to global warming. However, it is very difficult to measure the total representative volume of landfill gas from a landfill site, because various landfill gases are heterogeneously emitted from gas venting tubes, and also from the surface of the landfill site. It is also well known that $\mathrm{CH}_{4}$ is heterogeneously emitted from waste treatment facilities, such as composting facilities and biogasification facilities.

To obtain a representative emission of $\mathrm{CH}_{4}$ from a landfill site and a waste treatment facility (waste disposal facility), it is necessary to obtain many samples from the gas venting tubes and the ambient air at the landfill site and waste disposal facility, and then analyze the collected 
samples. This is very laborious, time consuming, and costly, and there are hopes that a new and simple method for monitoring $\mathrm{CH}_{4}$ in ambient air can be developed to provide the desired information in a cost-effective manner.

We have investigated the use of a portable open path-type analyzer for monitoring representative values of $\mathrm{CH}_{4}$ at waste disposal sites that is quicker and easier to use than conventional analyzers $[1,2]$. We reported on a method for using these portable open path-type methane analyzers that was convenient and usable for monitoring the average concentration of $\mathrm{CH}_{4}$ in ambient air at a landfill site [1]. In this study, we have investigated a practical application for monitoring $\mathrm{CH}_{4}$ in ambient air at a waste disposal facility using a portable open path-type methane analyzer, and have examined the characteristics of $\mathrm{CH}_{4}$.

\section{MATERIALS AND METHODS}

\subsection{Instrument and its principle of operation}

Figure 1 shows a photograph of a portable open path methane analyzer (POMA) that is retailed as an urban gas leak detector. The POMA consists of an electronics unit, an optics unit, and a connecting tube. It has an InGaAsP distributed-feedback laser light source in the electronics unit. The wavelength of the laser is stabilized at an absorption line of methane (the 1,640-1,700 $\mathrm{nm}$ band of the $\mathrm{R}(3)$ line $(\lambda=1.65372 \mu \mathrm{m}))$ that is free from interference from atmospheric gases. The laser light is coupled to a single-mode optical fiber in the connecting tube and guided to the optics unit. Table $I$ shows the specifications and performance of the POMA.

A schematic method for monitoring the concentration of $\mathrm{CH}_{4}$ using the POMA is shown in Figure 2. The optics unit transmits the laser beam to the special reflector, and part of the backscattered light is condensed onto a

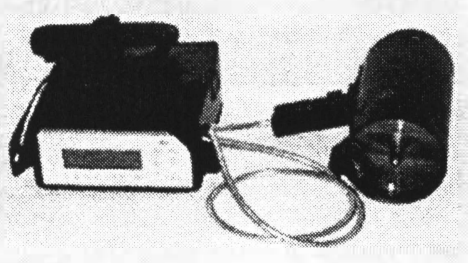

Figure 1. The portable open path methane analyzer used photodetector. The photodetector output is fed

Table 1. The specifications and performance of the the portable open path type methane analyzer

\begin{tabular}{|c|c|}
\hline Detection principle & $\begin{array}{l}\text { Wavelength-modulation } \\
\text { spectroscopy for infrared absorption }\end{array}$ \\
\hline Light source & InGaAsP distributed-feedback laser \\
\hline Wavelength $(\mathrm{nm})$ & 1653.7 \\
\hline Response time (s) & 0.1 \\
\hline Detection distance $(\mathrm{m})$ & $<30$ \\
\hline Lower detection limit $(\mathrm{ppm} \bullet \mathrm{m})$ & 50 \\
\hline Upper detection limit $(\mathrm{ppm} \bullet \mathrm{m})$ & 6000 \\
\hline Weight (kg) & $\begin{array}{l}4.4 \text { in total } \\
\text { (Electronics unit : } 3.2, \text { Optics unit : } \\
0.9, \text { Connecting tube : } 0.3 \text { ) }\end{array}$ \\
\hline Dimensions (mm) & $\begin{array}{l}\text { Electronics unit : W 195, D 260, H88 } \\
\text { Optics unit : W 114, D 244, H206 }\end{array}$ \\
\hline Battery & Nickel-metal hydrate battery $(12 \mathrm{~V})$ \\
\hline
\end{tabular}


into the electronics unit, and this is converted into the absorption factor of the laser light. The POMA measures the path-integrated methane concentration (in units of $\mathrm{ppm} \cdot \mathrm{m}$ ) between the optical unit and the special reflector. The concentration of $\mathrm{CH}_{4}$ is calculated using Equation I

$$
\mathrm{CH}_{4}(\text { in } \mathrm{ppm})=\mathrm{M} / \mathrm{X}
$$

where $\mathrm{M}=$ the path-integrated methane concentration (in units of $\mathrm{ppm} \cdot \mathrm{m}$ ) and $\mathrm{X}=$ the distance (in $\mathrm{m}$ ).

\subsection{Method}

The concentration of $\mathrm{CH}_{4}$ in ambient air measured by varying the distance between the POMA and the special reflector, at two landfill sites (Landfill sites A and B) is shown in Table 2, at three kitchen waste biogasification facilities (Facilities C, D, and E) in Table 3, and at a composting facility (Facility F) in Table 4.

Landfill site A was a controllable closed system disposal facility (CSDF), which is increasingly being used in Japan. A CSDF has a barrier, such

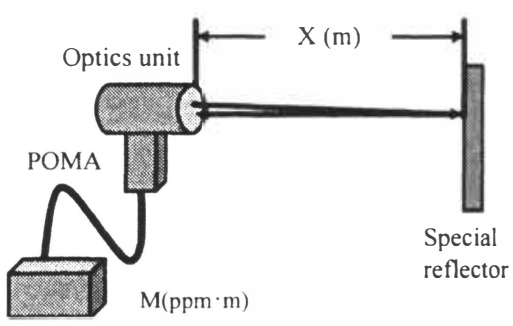

Electronics unit

Figure 2. A schematic drawing of the method for monitoring the concentration of $\mathrm{CH}_{4}$ using the POMA as a roof or an artificial foundation that can prevent rainfall from infiltrating the waste. The physical conditions (e.g., temperature and water content) within the waste layers can be controlled, depending on the quality of the landfilled waste, without imposing any impact on the environment. Landfilled waste is pulverized incombustible waste, plastics, and ash. It is estimated that these have a low content of easily biodegradable organic matter. The POMA and the special reflector were positioned at a height of $7 \mathrm{~m}$ above the landfill surface at opposite ends of the landfill site, spaced about $38 \mathrm{~m}$

\begin{tabular}{lcc}
\hline \multicolumn{3}{c}{ Table 2. Outline of landfill site tested } \\
\hline $\begin{array}{l}\text { Buration of } \\
\text { reclamation }\end{array}$ & Landfill side A & Landfill site B \\
\hline $\begin{array}{l}\text { Reclamation } \\
\text { area }(\mathrm{m} 2)\end{array}$ & 1000 & $1979-$ \\
\hline $\begin{array}{l}\text { Landfilled } \\
\text { solid waste }\end{array}$ & $\begin{array}{r}\text { Pulverized } \\
\text { incombustible waste } \\
\text { and plastics, Ash }\end{array}$ & Domestic waste \\
\hline
\end{tabular}
apart, and the concentration of $\mathrm{CH} 4$ between them was periodically measured. For comparison, the air at the midpoint between the optical unit and the special reflector (Point G) was sampled using a plastic tube, and the sample gas was introduced into the continuous $\mathrm{CH}_{4}$ analyzer. Its specifications are shown in Table 5. The air at Point H, Point I, and Point J,

Table 3. Outline of kitchen waste biogasification facilities tested

Facility C Facility D Facility E

\begin{tabular}{lccc}
\hline $\begin{array}{l}\text { Fermentation } \\
\text { temperature }\left({ }^{\circ} \mathrm{C}\right)\end{array}$ & 55 & 35 & 55 \\
$\begin{array}{l}\text { Treatment capacity of } \\
\text { kitchen waste }\end{array}$ & 22 & 55 & 16 \\
\hline $\begin{array}{l}\text { Population in } \\
\text { communities }\end{array}$ & 41,000 & 94,000 & 42,000 \\
\hline
\end{tabular}

Table 4. Outline of composting facility
(Facility $F)$


shown in Figure 3, was intermittently sampled into plastic bags through a plastic tube and the concentration of $\mathrm{CH}_{4}$ was measured using the continuous $\mathrm{CH}_{4}$ analyzer.

Landfill site B was divided into four sections. Domestic waste, including kitchen garbage, was sent to direct landfill. It is estimated that much organic matter was present at Landfill site $\mathrm{B}$. The concentration of $\mathrm{CH}_{4}$ was measured in each section at a height of about $1.5 \mathrm{~m}$ using the POMA.

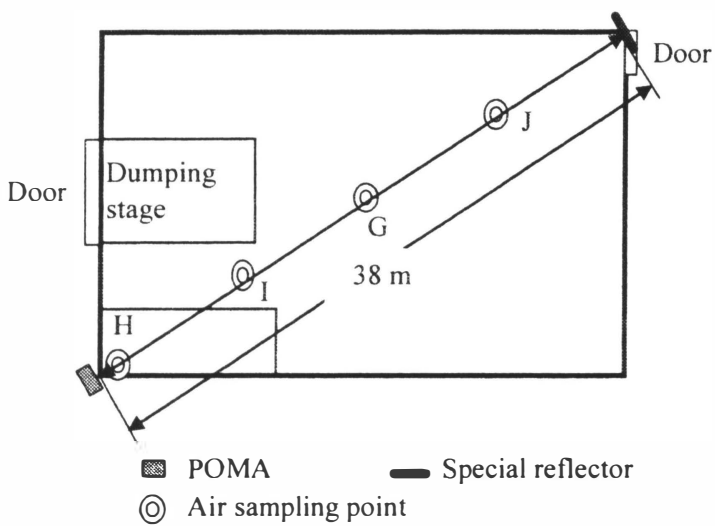

Figure. 3 An outline of the monitoring of the concentration of $\mathrm{CH}_{4}$ at Landfill site

The main equipments were located in rooms at the kitchen waste biogasification facilities. The concentration of $\mathrm{CH}_{4}$ in ambient air in the main rooms, where $\mathrm{CH}_{4}$ might leak, was measured. The concentration of $\mathrm{CH}_{4}$ in ambient air at a composting facility was also measured.

Table 5. The specifications of the conventional $\mathrm{CH}_{4}$ analyzer

\begin{tabular}{lcc}
\hline $\begin{array}{c}\text { Measurement } \\
\text { principle }\end{array}$ & $\begin{array}{c}\text { Range } \\
(\mathrm{ppm})\end{array}$ & $\begin{array}{c}\text { Sample flow } \\
(\mathrm{ml} / \mathrm{min})\end{array}$ \\
\hline $\begin{array}{l}\text { Flame ionization } \\
\text { detector method }\end{array}$ & $0-10$ & 900 \\
\hline
\end{tabular}

\section{RESULTS AND DISCUSSION}

\subsection{Landfill sites}

At Landfill site $\mathrm{A}$, the concentration of $\mathrm{CH}_{4}$ varied over the range $2-4 \mathrm{ppm}$. This is higher than the level in the outside air, because it contains a contribution from the landfill gas. Examples of the change in $\mathrm{CH}_{4}$ concentration measured by the POMA and the continuous $\mathrm{CH}_{4}$ analyzer at Point $\mathrm{G}$ are shown in Figure 4. When essential works (for example, dumping or bulldozing of the waste) is carried out at Landfill site A. the door of the landfill site is opened, and the air ventilators are operated. As illustrated in Figure 4. measurements were recorded for a period of $18 \mathrm{~min}$, and then the door was opened, and the air charging system was

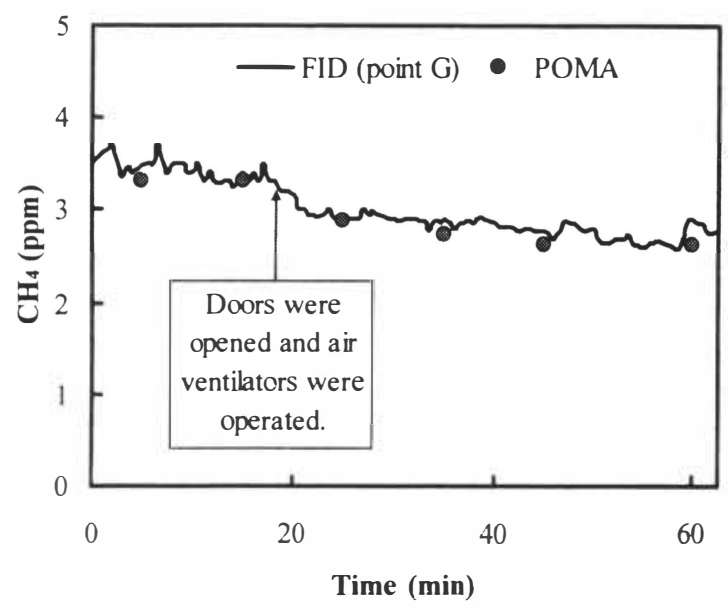

Figure 4. An example of the change in concentration of $\mathrm{CH}_{4}$ at L andfill site $\mathrm{A}$ 
operated. During the initial $18 \mathrm{~min}$, the concentration of $\mathrm{CH}_{4}$ measured by the POMA was approximately equal to that measured by the continuous $\mathrm{CH}_{4}$ analyzer. After $18 \mathrm{~min}$, the concentration of $\mathrm{CH}_{4}$ measured by the POMA and the continuous $\mathrm{CH}_{4}$ analyzer decreased gradually as the outside air entered and diluted the methane-rich air inside. The concentration of $\mathrm{CH}_{4}$ measured by the POMA was also approximately equal to that measured by the continuous $\mathrm{CH}_{4}$ analyzer.

An example of the change in $\mathrm{CH}_{4}$ concentration measured by the POMA and that at Points $\mathrm{G}, \mathrm{H}$, $\mathrm{I}, \mathrm{J}$ using the continuous $\mathrm{CH}_{4}$ analyzer is shown in Figure 5. During the initial $18 \mathrm{~min}$, there were differences in the concentration of $\mathrm{CH}_{4}$ at Points $\mathrm{G}, \mathrm{H}, \mathrm{I}, \mathrm{J}$, and the mean $\mathrm{CH}_{4}$ concentration at Points $\mathrm{G}, \mathrm{H}, \mathrm{I}, \mathrm{J}$ were approximately equal to those measured by the POMA. After $18 \mathrm{~min}$, the outside air entered and mixed with the inside air. After this had occurred, there was little difference between the $\mathrm{CH}_{4}$ concentration at Points $\mathrm{G}, \mathrm{H}, \mathrm{I}, \mathrm{J}$, and that from the POMA. Namely, it was clear that the POMA can monitor representative values of $\mathrm{CH}_{4}$ concentration in the landfill site where $\mathrm{CH}_{4}$ is heterogeneously emitted.

The results of $\mathrm{CH}_{4}$ in ambient air at Landfill site $\mathrm{B}$ are shown in Table 6. Domestic waste, including kitchen waste, is sent to landfill at Sections 3 and 4. It seems that large volumes of landfill gas are emitted at Sections 3 and 4 , as the organic matter contained in the waste is activel! degrading. More than 20 years have passed since Section 1 was completed, and more than 10 years have passed since Section 2 was completed. The peak activity of the organic degradation in each section is considered to have passed, and the volume of landfill gas produced has reduced. The concentration of $\mathrm{CH}_{4}$ in ambient air at Sections 3 and 4 was higher than at Sections 1 and 2 . The maximum reading observed was $30 \mathrm{ppm}$. The concentration

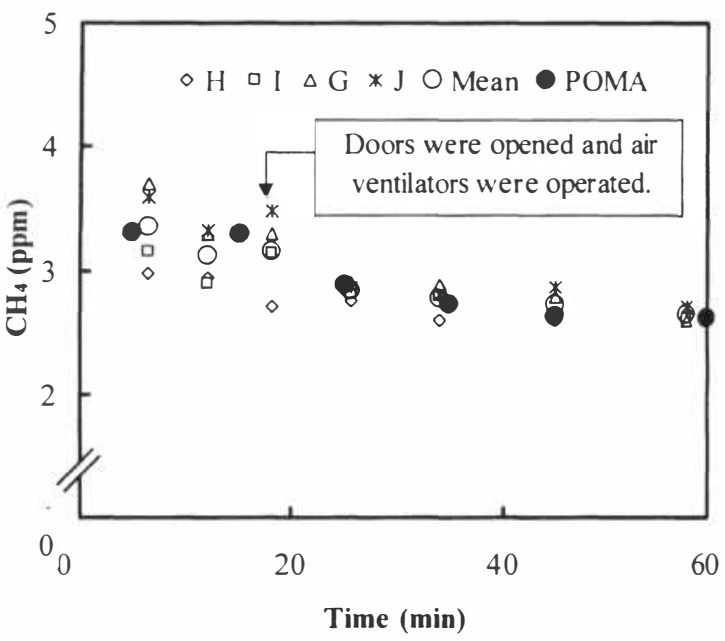

Figure 5. Another example of the change in concentration of $\mathrm{CH}_{4}$ at Land'fill site $A$

Table 6. $\mathrm{CH}_{4}$ in ambient air Sections 3 and 4.

\subsection{Biogasification facilities and composting facility}

$\mathrm{CH}_{4}$ in ambient air in the main rooms of the kitchen waste biogasification facilities could be conveniently and quickly measured by the POMA. at Landfill site $A$ Duration of $\mathrm{CH}_{4}$

\begin{tabular}{lcc} 
& at Landfill site $A$ \\
\hline & $\begin{array}{c}\text { Duration of } \\
\text { reclamation }\end{array}$ & $\begin{array}{c}\mathrm{CH}_{4} \\
(\mathrm{ppm})\end{array}$ \\
\hline Section 1 & $1979-1983$ & $3.3-6.0$ \\
\hline Section 2 & $1984-1992$ & $1.8-5.2$ \\
\hline Section 3 & $1993-$ & $1.8-9.6$ \\
\hline Section 4 & $1999-$ & $2.9-30.0$ \\
\hline
\end{tabular}


The results are shown in Table 7. This data changed, depending on the conditions of the room (e.g., type of operation, volume, sealing, and ventilation), and the values were small and therefore, negligible. Test equipment is available to detect accidental $\mathrm{CH}_{4}$ leaks, which can measure the concentration of $\mathrm{CH}_{4}$ at the percent level. The POMA is more useful for a rapid early detection of accidental $\mathrm{CH}_{4}$ leaks, as it can monitor the concentration of $\mathrm{CH}_{4}$ at the ppm level.

The results measured by the POMA in the central region of the composting facility are shown in Table 8. The

\begin{tabular}{lccc} 
Table 8. $\mathrm{CH}_{4}$ in ambient air at \\
the composting facility \\
\hline Height $(\mathrm{m})$ & 1 & 2 & 3 \\
\hline $\mathrm{CH}_{4}(\mathrm{ppm})$ & 4.6 & 7.2 & 12.8 \\
\hline
\end{tabular}
concentration of $\mathrm{CH}_{4}$ depended on the measurement height. The concentration of $\mathrm{CH}_{4}$ at a height of $1 \mathrm{~m}$ was lower than that at a height of $3 \mathrm{~m}$. It is presumed that the gases that are emitted by the degradation of organic matter, which includes $\mathrm{CH}_{4}$, rise, and are diluted as their temperature increases. The concentration of $\mathrm{CH}_{4}$ at a height of $1 \mathrm{~m}$ varied with changes in location. and was in the range 3-6 ppm. This was because of the active degradation area in the composting equipment was limited.

\section{CONCLUSIONS}

We have developed a practical application for monitoring $\mathrm{CH}_{4}$ in ambient air at waste disposal facilities using a portable open path-type methane analyzer, and have used it to investigate and characterize the concentration of $\mathrm{CH}_{4}$ in ambient air. The following conclusions were reached:

- A POMA can conveniently and quickly monitor the concentration of $\mathrm{CH}_{4}$ in ambient air at landfill sites, kitchen waste biogasification facilities, and composting facilities, where $\mathrm{CH}_{4}$ may be emitted heterogeneously.

- The concentration of $\mathrm{CH}_{4}$ varied over the range, 2-4 ppm at the landfill sites where pulverized incombustible waste, plastics, and ash were landfilled.

- The concentration of $\mathrm{CH}_{4}$ varied over the range, 2-30 ppm at the landfill sites where domestic waste, including kitchen garbage, was directly landfilled.

- The concentration of $\mathrm{CH}_{4}$ varied over the range, 2-13 ppm at the kitchen waste biogasification facilities.

- The concentration of $\mathrm{CH}_{4}$ varied over the range, 3-13 ppm at the composting facility.

\section{ACKNOWLEDGEMENT}

The Authors wish to thank the Anritsu Co. and Mr. Yukio Kamiegawa for valuable assistance. 


\section{REFERENCES}

[1] Tanikawa N., Furuichi T., Ishii K., and Matsuo K., 2004. Development of convenient monitoring method of methane in ambient air at landfill sites using portable open path type analyzer. In: Proceedings of the $3^{\text {rd }}$ Asian Pacific Landfill Symposium, Kitakyushu, Japan, pp. 411-416.

[2] Tanikawa N., Furuichi T., and Ishii K., 2003. Monitoring of methane and carbon dioxide in ambient air at landfill sites. In: Proceedings of the 9th International Waste Management and Landfill Symposium, Sardinia 2003. Sardinia, Italy. 